\title{
Peyzaj Tasarım Projelerinde, Metraj, Keşif ve Yaklaşık Maliyet Analizi
}

\author{
Deniz ÇELIKK ${ }^{1 *}$ \\ ${ }^{1}$ Bartın Üniversitesi, Meslek Yüksek Okulu, Park ve Bahçe Bitkileri Bölümü,74100, BARTIN
}

\section{Öz}

Kentlerde yapı adaları ve sirkülasyon sisteminin yanı sıra açık-yeşil alanlar yer almaktadır. Bu açık-yeşil alanlarda parklar, meydanlar, çocuk oyun alanları, konut bahçeleri gibi kamusal, özel veya yarı özel mekanlar bulunmaktadır. Bu alanların planları ve tasarım projeleri peyzaj mimarları tarafından yapılmaktadır. Tasarım projeleri süreci birkaç aşamadan oluşmaktadır. Bunlar, sörvey, leke plan, avan proje, kesin proje, yapısal ve bitkisel peyzaj uygulama projeleri ve detay projeleridir. Ayrıca açıklama raporu da tasarımdan sonra hazırlanmaktadır. Tasarımı gerçekleştirilen projelerin uygulama aşamasına geçmeden önce de metraj, keşif ve maliyet hesaplarının yapılması gerekmektedir. Bu hesaplamalar sırasında uygulama ve detay projeleri ile teknik şartnamelere ihtiyaç duyulmaktadır. Bu bağlamda araştırmanın amacı, Çankaya Belediyesi Yıldız İlçesinde bir apartman projesi özelinde peyzaj tasarım projesini, metraj, keşif ve yaklaşık maliyet hesaplamalarını yapmaktır. Böylece projeyi talep eden kişiler uygulamaya geçmeden önce ayırmaları gereken bütçeyi bilme ve ona göre planlama yapma imkanı bulabileceklerdir. Sonuç olarak, bu çalışma yaklaşık maliyet hesaplamalarının günümüzde nasıl yapılabileceğine yönelik bir örnek oluşturacak ve literatüre katkı sağlayacaktır.

Anahtar Kelimeler: Peyzaj tasarımı, metraj, keşif, maliyet analizi, uygulama.

\section{Quantity Survey, Price Calculation and Approximate Cost Analysis in Landscape Design Projects}

\begin{abstract}
In addition to building blocks and circulation system, there are open-green spaces in the cities. In these opengreen spaces, there are such public, private or half-private areas as parks, squares, playgrounds and gardens of residences. The planning and design projects of these spaces are made by landscape architects. Designing process involves a few phases. These phases are survey, concept plan, preliminary design, final design, structural and planting landscape application projects and detail drawings. Besides, the explanation report is prepared after the design. Before the application of the designed projects, it is necessary to make quantity survey, price calculation and cost calculations. During these calculations, construction projects, detail projects and technical specifications are needed. In this context, the purpose of this study is to make the landscape design project, quantity survey, price calculation and approximate cost calculation of a building project in Yıldız district of Çankaya Municipality. Thus, those who demand a project will know the budget they should allocate and make their planning accordingly, before they application the project. As a result, this study will serve as a sample towards how to do approximate cost calculations today and contribute to the literature.
\end{abstract}

Keywords: Landscape design, quantity survey, price calculation, cost analysis, application. 


\section{Giriş}

Kentsel peyzajın oluşmasında açık-yeşil alanları oluşturan kamusal alanların yanı sıra özel ve yarı özel alanlar da önemli roller üstlenmektedir. Aynı zamanda bu alanlar kent estetiğinin oluşmasına katkıda bulunmaktadır. $\mathrm{Bu}$ nedenle tasarım kadar, tasarımı yapılmış projelerin tekniğine uygun ve önerilen malzemelerle doğru olarak alana uygulanması da gerekmektedir. Özellikle uygulama sürecini kontrol altına almak ve zamanında uygulayabilmek için yeterli bütçenin ayrılması önem taşımaktadır. Bu nedenle tasarım tamamlandıktan yapısal ve bitkisel peyzaj uygulama projeleri ve detay projeleri hazırlandıktan sonra teknik şartnamelerin hazırlanması, metraj, keşif, birim fiyat analizleri ve yaklaşık maliyet hesaplarının yapılması gerekmektedir.

Peyzaj mimarları alanın doğal ve kültürel verilerini kullanarak, hem fonksiyonel hem de estetik amaçlı proje üretmektedir. Aynı zamanda koruma-kullanma dengesini gözeterek, projelerin ekolojik, ekonomik, bilimsel ve sanatsal ölçütlere uygun olmasına da özen göstermektedir. Projelerin tasarım süreci sörvey, leke plan, avan proje, kesin proje, yapısal ve bitkisel peyzaj uygulama projeleri, detay projeleri, açıklama raporunun hazırlanması gibi aşamaları içermektedir (Barış, 2004; Korkut vd., 2010; Seçkin vd., 2011, PMO, 2017). Tasarım sürecinde nokta, çizgi, form, renk gibi tasarım elemanları ile yapısal ve bitkisel kompozisyon sırasında tekrar, denge, birlik, zıtlık, vurgu gibi tasarım ölçütleri kullanılmaktadır (Gürer, 1990; Reid, 1993; Hiss ve Booth, 2002).

Tasarımı bitmiş olan projenin uygulama aşamasına geçmeden önce ise metraj ve keşfin yapılması gerekmektedir. Metraj uygulamada kullanılacak toplam malzeme miktarının bulunması, keşif ise maliyetin hesaplanması olarak tanımlanmaktadır (Hasol, 2005). Daha geniş anlamda metraj projede bulunan tüm imalat miktarını m, m2, m3, kg, adet vb. olarak hesaplamaktır. Keşif, ise hesaplanan metrajların her bir iş kalemi için birim fiyat cetvellerinden temin edilen birim fiyatlarla ayrı ayrı çarpılması ile elde edilmektedir. Daha sonra her iş kalemi için bulunan maliyetler toplanarak projenin keşif özeti hesaplanmaktadır. Yapısal, bitkisel peyzaj işleri, sulama, aydınlatma gibi uygulamaya yönelik tüm işlerin keşif özetleri toplanarak uygulanacak projenin keşif sonucu elde edilmektedir (Seçkin, 2003).

Metraj ve keşif hazırlarken uygulama ve detay projeleri çok önemli veri kaynaklarıdır. Bu projelerden uygulamaya yönelik teknik bilgileri sistem detaylarını, uygulama ve üretime yönelik malzemelerin teknik detaylarını, malzeme niteliğini, tekniğine uygun ölçülendirmeyi, malzemenin içeriğini, katmanları gibi bilgileri temin etmek mümkündür (PMO, 2006; PMO, 2017).

Tasarımı yapılan projenin uygulanması için teknik şartnamelerin hazırlanması gerekmektedir. Teknik şartname projenin tekniğine uygun olarak uygulanabilmesi için gerekli tüm sistematik ve bilimsel verileri içermektedir. İmalat ve uygulamaya yönelik olan fakat çizili belgelerde bulunmayan bilgiler bu şartnamelerde yer almaktadır. Kısaca, teknik şartnameler, projelerde tasarlanan tüm imalat ve malzemelerin üretim şekli, özellikleri, imalata sokuluş koşulları, imalatlarında ve montajlarında dikkat edilmesi gereken hususları, işçiliklerin tarifi, ölçüm ve deney şekli, söz konusu imalatın diğer imalatlarla birleşme- ayrılma biçimleri, taşıma, yükleme, tasnif, istifleme gibi koşulları belirleyen yazılı belgelerdir (PMO, 2006).

Keşif projeler üzerinden hesaplanan metrajlar doğrultusunda ilgili resmi kurumların yayınladığı birim fiyatlar üzerinden bulunmaktadır. Birim fiyatı olmayan işler için piyasa araştırması yapılmaktadır. Bu kapsamda farklı firmalardan proforma alınmakta ve birim fiyat analizleri düzenlenmektedir (PMO, 2006). Birim fiyat analizi, analiz yapılacak işlerin birim miktarlarının kaça mal olacağının hesaplanması yöntemidir. Birim fiyat cetveli ise, birim fiyat analizi sonuçlarının ve poz numaralarının bir tablo halinde verilmesidir. Bu cetveller Bayındırlık Bakanlığınca ya da ilgili bakanlıkça her yıl hazırlanmakta ve yayınlanmaktadır (Seçkin, 2003).

Bu bağlamda Ankara İl'inde 25.311 ada 13 parsel için Sakalar İnşaat Şirketi'nin talebi üzerine apartman bahçesine yönelik peyzaj tasarım projesi hazırlanmıştır. Tasarım sürecinde tasar öge ve ilkeleri, alanın mevcut özellikleri, kullanıcı istekleri temel alınmış ve proje çizilmiştir. Ayrıca projenin günümüzdeki uygulama bedelini bulmak için metraj, keşif ve yaklaşık maliyet hesabı yapılmıştır.

\section{Materyal ve Metot}

\subsection{Materyal}

Araştırmanın ana materyalini Çankaya Belediyesi Yıldız İlçesi sınırları içinde yer alan 25.311 ada 13 parsele ait peyzaj tasarım projesi oluşturmaktadır. Sakalar İnşaat Şirketi’nin talebi üzerine klasik parsel üzerinde yer alan ikiz apartmanların çevre düzenleme projesi yazar tarafından çizilip Çankaya Belediyesi’nin onayına 12.10.1993 
tarihinde sunulmuştur. Proje Çankaya Belediyesi tarafından 12.11.1993 tarihinde onaylanmıştır.

Proje alanı içinde iki adet beşer katlı ikiz apartman bulunmaktadır. Apartmanların giriş katları ticari birim olarak kullanılmaktadır. Alana giriş kuzey-doğu yönünden sağlanmaktadır. Apartmanlar birbirinden ayrı olarak inşa edilmiş olup, apartman girişleri karşılıklı olarak yer almaktadır. Ticari birimlerin girişleri apartmanların yola bakan cephesinden sağlanmaktadır. Projenin çizildiği 1993 yılında proje alanına girişi sağlayan cephede araç yolu, kuzey-batısındaki bitişik parselde inşaatı devam eden bina, güney-doğusundaki bitişik parselde mevcut gecekondu, güney-batısındaki bitişik parselde ise boş arsa bulunmakta olup günümüzde bu üç bitişik parselde de mevcut bina yer almaktadır. Projenin vaziyet planı Şekil 1'de verilmiştir.

Proje alanının yer aldığı Ankara İlinin güney kesimi İç Anadolu Bölgesine özgü iklim özellikleri göstermektedir. Bu bölgede kışları soğuk, yazları sıcak olan karasal iklim hüküm sürmektedir. Kışın karla geçen gün sayısı 30,5 gündür. Hakim rüzgar ise Haymana (İkizce), Sincan, Dikmen semti ve Nallıhan ilçelerinde Batı yönünde esmektedir (URL1, 2018).

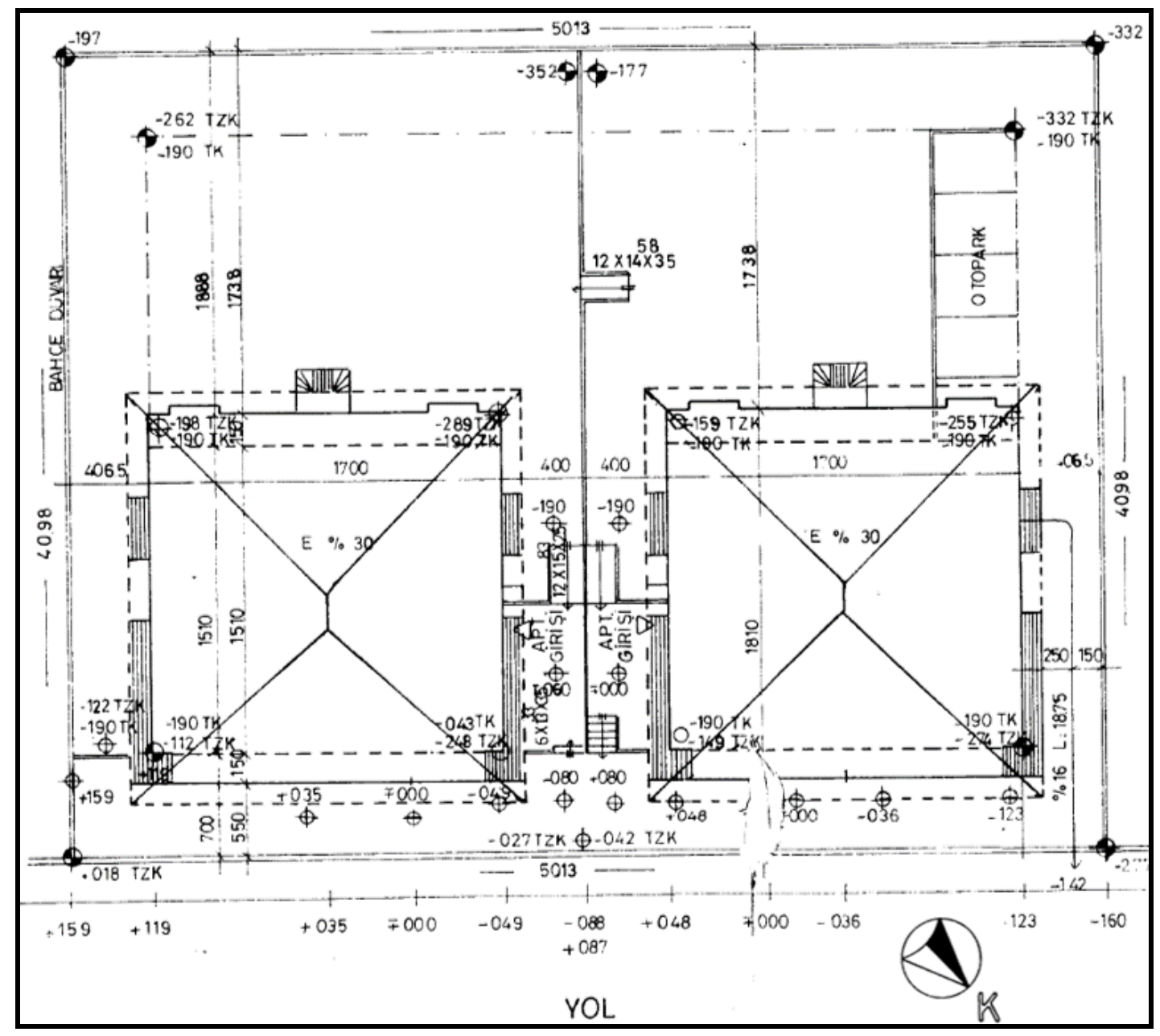

Şekil 1. 25.311 ada 13 parsele ait vaziyet planı

\subsection{Metot}

Araştırmanın metodu projenin tasarımı ve maliyet analizi olmak üzere iki bölümde gerçekleştirilmiştir. Birinci bölüm sörvey, avan proje, kesin proje, yapısal ve bitkisel peyzaj uygulama projeleri ve detay projelerinin çizimi aşamalarını kapsayan proje tasarım sürecidir. İkinci bölümde ise metraj, keşif ve kesin hesap listelerinin hazırlanarak yaklaşık maliyet hesabının yapılmasıdır.

\section{Tasarım aşaması}

Tasarım sürecinin sörvey aşamasında proje alanına gidilerek arazinin mevcut durumu saptanmış ve çevre analizi yapılmıştır. Alanın doğal ve fiziksel özeliklerine yönelik veriler temin edilmiştir. Bu kapsamda konum, 
topoğrafik yapı, hakim rüzgar yönü, güneşli/gölgeli mekanlar, güzel görüntü, kötü koku kaynakları gibi veriler elde edilmiştir. Apartmanlara ait kat planlarının olduğu mimari projeler temin edilip, altyapı projeleri sorgulanmıştır. Avan proje hazırlanması aşamasında kullanıcıların talepleri ve ihtiyaçları saptanarak ihtiyaç listesi yapılmıştır. İki apartmanın da kullanabileceği çocuk oyun alanına, dinlenme mekanı, otopark alanı ve bu mekanları birbirine bağlayan yaya sirkülasyonuna ihtiyaç duyulmuştur. Bu kapsamda arazinin topoğrafyası, iklimsel özellikleri, bitişik parseldeki kullanımlar dikkate alınarak sirkülasyon sistemi kurulmuş ve mekânsal kullanım alanları belirlenmiştir.

Projenin yapısal tasarım aşamasında güneşlenme imkanı ve bahçenin mevcut durumu dikkate alınarak çocuk oyun alanı güney, dinlenme alanı batı yönünde tasarlanmıştır. Kışları soğuk ve kar yağışlı, yazları sıcak geçen iklim özelliği görülen alanda zemin döşeme malzemesinde kaymayan yüzeyler tercih edilmiştir. Tasarımda tekrar, uyum, denge, simetri ve zitlık ilkleri kullanılmıştır. Örneğin, zeminde beton parkelerde tekrar ilkesi uygulanmıştır. Uyum ilkesi kentsel donatı elemanlarında renk ve malzeme seçiminde gerçekleştirilmiştir. Farklı form ve boyuttaki kentsel donatı elemanları tercih edilerek de zitlık ilkesi vurgulanarak monotonluğun giderilmesi sağlanmıştır.

Bitkisel tasarım aşamasında bitkilerin fonksiyonel ve estetik özellikleri ön planda tutulmuştur. Bu özellikler, alanı sınırlama; renk, koku, çiçek etkisi yaratma; alan kullanıcılarına güvenli mekan oluşturma; çatı etkisi yaratma gibi özelliklerdir (Tokol, 2000). Bunun yanı sıra ağaçlar doğu-güneydoğu ve batı-güneybatı yönünde sıralar halinde kullanıldığında en iyi gölgelemeyi yapmaktadır (Taşpınar, 1977). Aynı zamanda bitkilerin hem dendrolojik özellikleri hem de ekolojik istekleri dikkate alınmıştır. Mekanla ölçek/ boyut bakımından uyum sağlayacak çiçek, koku, renk etkisi olan ağaç, ağaççı, çalı forumundaki yapraklı ve ibreli bitkiler tercih edilmiştir. Ayrıca dört mevsim yeşil renk vurgusunu yaratmak için daha çok çalı formundaki herdemyeşil bitkiler kullanılmıştır. Bitkiler girişleri vurgulamak için 3-5'li gruplar halinde uygulanmıştır. İç mekandan dışarıya bakan kişinin görüşünü engellemeyecek şekilde tasarım yapılmıştır. Yine ticari birimlerin vitrinlerini kapatmayacak şekilde yatay gelişen çalı grupları tercih edilmiştir.

$\mathrm{Bu}$ ölçütler doğrultusunda hazırlanan avan proje alan kullanıcıları ile paylaşılmış, onların onayını aldıktan sonra kesin proje aşamasına geçilmiştir. Kesin proje aşamasından sonra yapısal ve bitkisel peyzaj uygulama projeleri, daha sonrada detay projeleri hazırlanmıştır.

\section{Metraj, keşif, yaklaşık maliyet analizi aşaması}

$\mathrm{Bu}$ aşamada öncelikle yapısal ve bitkisel peyzaj uygulama ve detay projelerinden elde edilen verilerle canlı ve cansız malzemenin metrajı çıkarılmıştır. Daha sonra her iş kalemi için poz numaraları ve birim fiyatları bulunmuş̧ur. Daha önceki yıllarda uygulamada yer alan iş kalemlerine ait poz numaraları ve birim fiyatları "Bayındırlık ve İskan Bakanlığı Genel Fiyat Analizlerinden Türetilen İnşaat Birim Fiyat Analizleri” kitabına bakılarak bulunmaktaydı. Fakat günümüzde teknolojinin gelişmesi ve iletişimin artması internet ortamında verilere ulaşmayı kolaylaştırmaktadır. Bu nedenle herhangi bir yapı işinin Poz numarası için Türkiye İnşaat ve Tesisat Birim Fiyatları https://www.birimfiyat.net/ adresinden sorgulama yapılabilmektedir. Bu adreste Çevre ve Şehircilik Bakanlığı, Devlet Su İşleri, Orman Genel Müdürlüğü, Köy Hizmetleri, Vakıflar Genel Müdürlüğü, Kültür ve Turizm Bakanlığı ve ilgili diğer kurumların pozları da yer almaktadır (URL2, 2018).

Pozlarda verilen fiyatlarda nakliye, işçilik ve yüklenici kârı dahil, Katma Değer Vergisi (KDV) hariçtir. Güncel fiyatı bulunamayan işler için Kamu İhale Kurulu Kararlarına göre "Parasal Tutar Güncelleme Yİ-ÜFE (Yurt İçi Üretici Fiyat Endeksi) ile Güncelleme" yapılarak güncel fiyat bulunabilmektedir ve poz numarasının sonuna "A (Analiz)" harfi yazılmaktadır. Tesviye betonu analizinde güncelleme yapılarak birim fiyatı bulunmuştur (URL3, 2018) Uygulama projelerinin keşifleri bilgisayar programları kullanılarak hazırlanmaktadır. Böylece, zaman ve emekten tasarruf etmek mümkün olmaktadır. Günümüzde hakediş ve yaklaşık maliyet hesaplamalarında AMP, OSKA vb. programlar kullanılmaktadır.

Birim fiyatlarda analizi bulunmayan özel işlere yönelik fiyatlarda ise fiyat analizlerinin yapılması gerekmektedir. Bu amaçla piyasadan en az üç adet fiyat teklifi alınmaktadır. Çoğunlukla en düşük fiyat tercih edilip maliyet hesaplaması bu fiyata göre yapılmaktadır. Özel analize kentsel donatı elemanları, bitkiler, özel imalatlar vb. girmektedir.

Projeye yönelik elde edilen metrajlar, iş kalemlerinin poz numaralarından elde edilen birim fiyatlarla çarpılarak keşifleri bulunmuştur. Yapısal ve bitkisel keşfin toplamıyla da yaklaşık maliyet hesabı yapılmıştır. Hesaplarda 2018 yılı birim fiyatları kullanılmıştır. 


\section{Bulgular ve Tartışma}

\subsection{311 ada 13 parsele ait yapısal ve bitkisel peyzaj uygulama projesi}

25.311 ada 13 parsel içinde bulunan apartmanlar -1.90 kotuna inşa edilmişlerdir. Fakat proje alanı girişinin sağındaki apartmana (A) +0.00, giriş katındaki ticari birime -0.36 ; solundaki apartmana (B) -0.60 , giriş katındaki ticari birime ise +0.35 kotu ile giriş sağlanmaktadır. A apartmanının arka bahçe eğimi mevcutta \%6; B apartmanınki ise \%3,5'tir. A apartmanının arka bahçesine dinlenme mekanı ve 5 araçlık otopark, B apartmanın arka bahçesine çocuk oyun alanı tasarlanmıştır. Kazı ve dolgunun olmaması için sert zeminler \%1,5-2 eğimde tasarlanmış, geri kalan eğim ise toprak zemin eğimiyle giderilmiştir. Bu mekanları birbirine ve apartmana bağlayan $1,70 \mathrm{~m}$ genişliğinde yaya yolları yapılmıştır. Bu yolların arka bahçede kalması ve ekonomik olması nedeniyle kullanıcılar tarafindan beton zemin olarak uygulanması istenmiştir. Apartmanların çevresine $1.00 \mathrm{~m}$. genişliğinde tretuvar yapılmıştır. Bahçe alanı çok büyük olmadığı için hortumla sulama istenmiştir. Sulama muslukları apartman içinde yer almaktadır. Parsel sınırına korkuluklu bahçe duvarı yapılmıştır. Yapısal ve bitkisel peyzaj uygulama projesi Şekil 2'de yer almaktadır.

Bitkisel peyzaj tasarımında ise ticari birim girişlerini vurgulamak, vitrinlerini kapatmamak ve iç mekandan dışarıya bakıldığında görüşü engellememek için yatay yönde gelişen Juniperus horizontalis Moench., tercih edilmiştir. Aynı zamanda herdemyeşil bu çalı ile yaz kış yeşil renk etkisi vurgulanmıştır. Alana girişi sağlayan yaya yolunun iki tarafinda da Euonymus japonicus Thunb. kullanılmıştır. Euonymuslar bir dizi olarak kullanılarak tam tekrar, karşılıklı yer alarak da simetri ilkesi uygulanmıştır. Otopark girişinde ise Thuja orientalis "Aurea Compacta"ya yer verilmiştir. Böylece bitkisel perde oluşturulmuştur. A apartmanının arka bahçesinde yer verilen dinlenme mekanında daha çok çiçek, renk ve kokularıyla ön planda olan bitkiler tercih edilmiştir. Tilia tomentosa Moench, Cercis siliquastrum L., Syringa vulgaris L., Philadelphus coronarius, Forsythia intermedia Zab., kullanılarak sarı, pembe ve mor renklerin ön plana çıkması sağlanmıştır. Ağaç ve çalılar 3 ya da 5'li gruplar halinde birbirini etkilemeyecek/ yarışmayacak şekilde kullanılmıştır. Pyracantha coccinea M.Roem ve Juniperus horizontalis Moench. ile de kışın alanın yeşil kalması sağlanmıştır. Ayrıca, Acer platanoides L.' e de yer verilerek mekanın gölgelenme düzeyi artırılmıştır. B apartmanının arka bahçesinde farklı bitkilere yer verilmiştir. Pinus nigra J. F. Arnold, Crataegus monogyna Jacq., Prunus cerasifera Popov kullanılmıştır. Çocuk oyun alanının olduğu yerde ise, Malus floribunda Siebold., Forsythia intermedia Zab., Philadelphus coronarius L. ve Juniperus horizontalis Moench. kullanılmıştır. Ölçek olarak çocuklarla uyum sağlaması için daha küçük ağaç ve çalılara yer verilmiştir. Bitkiler soliter ya da gruplar halinde kullanılmıştır. Farklı bu iki mekanı birbirine bağlayan yol üzerinde Berberis thunbergi DC. kullanılarak kırmızı renk vurgusu yapılmıştır. Arka bahçeyi kullananların kendilerini doğala yakın bir ortamda hissetmeleri için özellikle bitkisel düzenlemede asimetrik denge sağlanmıştır. Böylece alan kullanıcıları kendilerini daha rahat ve huzurlu hissedebileceklerdir.

\subsection{311 ada 13 parsele ait teknik şartname, metraj, keşif ve maliyet analizi}

25.311 ada 13 parsele ait tasarımı gerçekleştirilen peyzaj projesinde parsel alanı $2.055 \mathrm{~m}^{2}$, bina oturum alanı 514 $\mathrm{m}^{2}$, bahçe alanı $1.541 \mathrm{~m}^{2}$, sert zemin $691 \mathrm{~m}^{2}\left(578 \mathrm{~m}^{2}\right.$ beton zemin $+113 \mathrm{~m}^{2}$ beton parke $)$, çim alan $850 \mathrm{~m}^{2}$ dir. $113 \mathrm{~m}^{2}$ 'lik dinlenme alanına $8 \mathrm{~cm}$. kalınlığında beton parke taş döşenmiştir. Alan içinde $264 \mathrm{~m}$. bordür, $36 \mathrm{~m}$. oluk taşı uygulanmıştır. Beton zemin içinde yer alan $209 \mathrm{~m}^{2}$ 'lik otopark alanı hasır çelik takviyeli, $47 \mathrm{~m}^{2}$ 'lik çocuk oyun alanı $3 \mathrm{~cm}$ kalınlığında kauçuk malzeme ile kaplanmıştır. Makalede sınırlı sayfa sayısı nedeniyle projeye ait metraj, keşif ve yaklaşık maliyet analizinde yapısal ve bitkisel peyzaj uygulama projesinde yer alan temel iş kalemlerine yer verilmiştir. Bahçe duvarı, sulama ve aydınlatmada yer alan malzeme ya da işçiliğe yönelik herhangi bir hesaplama yapılmamıştır. Tablo 1'de yapısal metraj yer almaktadır.

Proje alanında ağaç, çalı ve sarılıcı olmak üzere toplam 142 adet bitki kullanılmıştır. Karasal iklim koşullarına uygun olarak dörtlü çim karşımı tercih edilmiş ve $\mathrm{m}^{2}$ 'ye 60 gr. çim tohumu kullanılmıştır. Karışımda \%35 oranında Festuca rubra rubra L. "Rosinante" (Kırmız1 yumak); \%30 oranında Lolium perenne L. "Allstarter" (İngiliz Çimi); \%20 oranında Poa pratensis L. "Bluechip" (Çayır salkım otu) ve \%15 oranında Festuca arundinacea Schreb "Tomcat” (Kamışsı yumak) yer almaktadır. Toplam çim tohumu miktarı 51 kg'dır. Bitkisel uygulama yapılacak $850 \mathrm{~m}^{2}$ 'lik alan üzerine 10-15 cm kalınlıkta bitkisel toprak, $3 \mathrm{~cm}$ torf ve $4 \mathrm{~cm}$ çiftlik gübresi serilmiştir. Bitkisel metraj Tablo 2'de bulunmaktadır. 


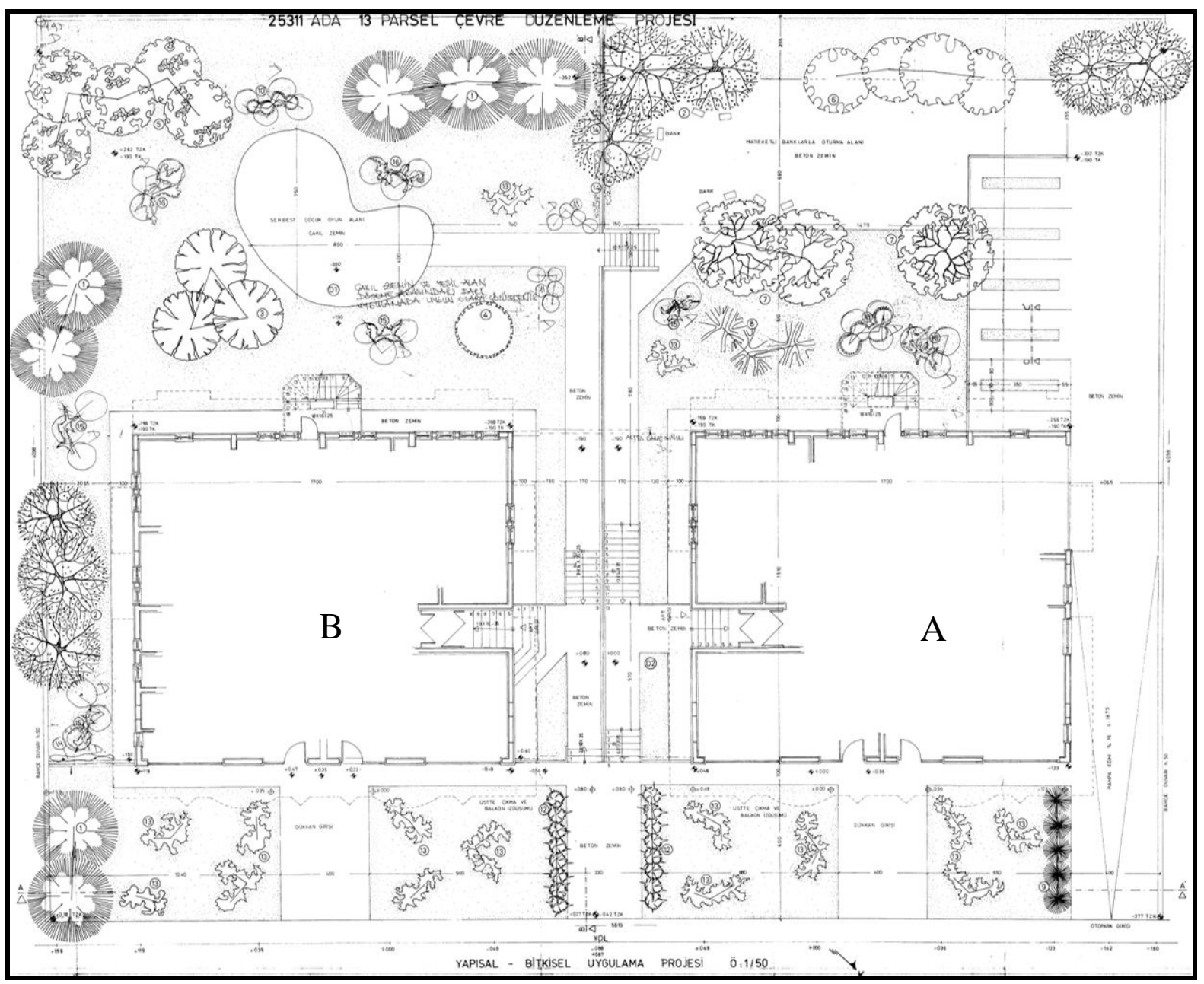

Şekil 2. 25.311 ada 13 parsele ait yapısal ve bitkisel peyzaj uygulama projesi

Tablo 1. Yapisal metraj

\begin{tabular}{|c|c|c|c|c|}
\hline Sira & Malzemenin Türü & Kullanıldığı Yer & Birim & Miktar \\
\hline 1 & $3 \mathrm{~cm}$ kalınlıkta Blok antistatik kauçuk zemin kaplaması & Çocuk oyun alanı & $\mathrm{m}^{2}$ & 47,000 \\
\hline 2 & Tesviye tabakası & Sert zemin & $\mathrm{m}^{2}$ & $\begin{array}{r}691,00 \\
0\end{array}$ \\
\hline 3 & Tek Kuleli Oyun Parkı & Çocuk oyun alanı & Adet & 1,000 \\
\hline 4 & Figürlü tahterevalli (4’lü) & Çocuk oyun alanı & Adet & 1,000 \\
\hline 5 & Alüminyum döküm ayaklı ahşap bank & Dinlenme alanı & Adet & 6,000 \\
\hline 6 & Kare metal dış mekan çöp kovası & Dinlenme alanı & Adet & 3,000 \\
\hline 10 & $\begin{array}{l}8 \mathrm{~cm} \text { yüksekliğinde normal çimentolu buhar kürlü beton } \\
\text { parke taşı }\end{array}$ & Dinlenme alanı & $\mathrm{m}^{2}$ & $\begin{array}{r}113,00 \\
0\end{array}$ \\
\hline 11 & $\begin{array}{l}50 \times 20 \times 10 \mathrm{~cm} \text { boyutlarında normal çimentolu buhar kürlü } \\
\text { beton bordür }\end{array}$ & $\begin{array}{l}\text { Tüm sert zeminlerin } \\
\text { kenarında }\end{array}$ & $\mathrm{m}$ & $\begin{array}{r}265,00 \\
0\end{array}$ \\
\hline 12 & $\begin{array}{l}\text { 30x10xserbestboy cm boyutlarında normal çimentolu } \\
\text { buhar kürlü beton oluk taşı }\end{array}$ & $\begin{array}{c}\text { Ticari birim ve alana } \\
\text { girişlerde yolun iki } \\
\text { yanında }\end{array}$ & $\mathrm{m}$ & 36,000 \\
\hline
\end{tabular}


Tablo 2. Bitkisel metraj

\begin{tabular}{|c|c|c|c|c|}
\hline Sira & Malzemenin Türü & Kullanıldığı Yer & Birim & $\begin{array}{c}\text { Miktar } \\
1\end{array}$ \\
\hline 1 & $3 \mathrm{~cm}$ Torf & Çim alan $\left(850 \mathrm{~m}^{2}\right)$ & $\mathrm{m}^{3}$ & 25,500 \\
\hline 7 & $\begin{array}{l}\text { Bitkisel uygulama yapılacak saha üzerine } 10-15 \mathrm{~cm} \\
\text { kalınlıkta bitkisel toprak }\end{array}$ & Çim alan $\left(850 \mathrm{~m}^{2}\right)$ & $\mathrm{m}^{3}$ & 127,500 \\
\hline 9 & $4 \mathrm{~cm}$ yanmış elenmiş çiftlik gübresi & Çim alan $\left(850 \mathrm{~m}^{2}\right)$ & $\mathrm{M}^{3}$ & 34,000 \\
\hline 10 & Peyzaj projesinde yer alan tüm bitkiler & Bitkisel uygulama alanı & Adet & 142,000 \\
\hline 11 & Lolium perenne L. "Allstarter" (İngiliz Çimi) & $51 \mathrm{~kg}$ çim tohumunun $\% 30$ 'u & $\mathrm{Kg}$ & 15,300 \\
\hline 12 & Poa pratensis L. "Bluechip" (Çayır salkım otu) & $51 \mathrm{~kg}$ çim tohumunun \%20 'si & $\mathrm{Kg}$ & 10,200 \\
\hline 13 & Festuca rubra rubra L."Rosinante" (Kırmızı yumak) & $51 \mathrm{~kg}$ çim tohumunun $\% 35$ 'i & $\mathrm{Kg}$ & 17,850 \\
\hline 14 & $\begin{array}{l}\text { Festuca arundinacea Schreb “Tomcat” (Kamışsı } \\
\text { yumak) }\end{array}$ & $51 \mathrm{~kg}$ çim tohumunun $\% 15$ ' $\mathrm{i}$ & $\mathrm{Kg}$ & 7,650 \\
\hline
\end{tabular}

Yapısal ve bitkisel iş kalemlerinde malzeme ve uygulamaya yönelik poz numaraları ve teknik şartname bilgileri Tablo 3 ve Tablo 4'de yer almaktadır. Ayrıca, tabloda metraj bilgileri ve uygulamadaki yüzdelik oranları (pursantajları) da bulunmaktadır. Tablo 3'de yer alan 7, 8 ve 9 sıra nolu iş kalemleri hasır çelikli otopark alanı için verilmiştir.

Tablo 3. Yapısal peyzaj işlerine ait teknik şartname ve metraj bilgileri

\begin{tabular}{|c|c|c|c|c|c|}
\hline $\begin{array}{l}\text { Sira } \\
\text { No }\end{array}$ & Poz No & İmalatın Cinsi & $\begin{array}{c}\text { Biri } \\
\text { m }\end{array}$ & Miktarı & $\begin{array}{c}\text { Pursantaj } \\
(\%)\end{array}$ \\
\hline \multirow[t]{2}{*}{1} & $04.032 / 20 \mathrm{~B}$ & $\begin{array}{l}3 \mathrm{~cm} \text { kalınlıkta Blok antistatik kauçuk zemin kaplaması, } \\
\text { Çarpma etkisini azaltan yüzey kaplamaları (TS EN 1176- } \\
1 \text {, TS EN 1177-1) }\end{array}$ & $\mathrm{m}^{2}$ & 47,000 & 3,092036 \\
\hline & \multicolumn{5}{|c|}{ Teknik Tarifi: Çarpma etkisini azaltan yüzey kaplamaları (TS EN 1176-1, TS EN 1177) } \\
\hline 2 & \multicolumn{5}{|c|}{$\begin{array}{l}\text { Teknik Tarifi: } \\
\text { Tesviye tabakası yapılacak yerin temizlenmesi, yıkanması, İdarece istenilen dozlu tesviye harcınır } \\
\text { hazırlanması } 3 \mathrm{~cm} \text { kalınlı̆̆ında mastarında sıkıştırılarak tesviye tabakası yapılması için gerekli her türli } \\
\text { işçilik, malzeme ve zayiat, makine, alet ve edevat giderleriyle, yükleme, taşıma, boşaltma, yüklenic } \\
\text { kârı ve genel giderler karşıllı̆ı dâhil yalnız çimento bedeli ile çimento ve agrega taşınması hariç tesviye } \\
\text { tabakası beher m² fiyatı. } \\
\text { Ölçü: Projedeki ölçülere göre tesviye tabakası yapılan yüzeyler hesaplanır. } \\
\text { Not: } \\
\text { a) } 3 \mathrm{~cm} \text { 'den daha fazla yapılan tesviye tabakasının } 3 \mathrm{~cm} \text { 'den fazla olan beton kısmı beton fiyatlarından } \\
\text { ödenir. } \\
\text { Üstteki } 3 \mathrm{~cm} \text { 'lik kısmın bedeli tesviye tabakası olarak ödenir. } \\
\text { b) Agrega taşınması için çimento miktarı (sayımla mukayese için) hesabında: } \\
1 \mathrm{~m}^{2} \text { tesviye tabakası için; } \\
\text { Agrega } 0.056 \mathrm{t} / \mathrm{m}^{2} \\
\text { Harç } 0.035 \mathrm{~m}^{3} / \mathrm{m}^{2} \text { değerleri alınacaktır. }\end{array}$} \\
\hline 3 & P-Özel 1 & Tek Kuleli Oyun Parkı & Adet & 1,000 & 9,344887 \\
\hline 4 & P-Özel 2 & Figürlü tahterevalli (4lü) & Adet & 1,000 & 4,485546 \\
\hline 5 & P-Özel 3 & Alüminyum döküm ayaklı ahşap bank & Adet & 6,000 & 4,485546 \\
\hline 6 & P-Özel 4 & Kare metal dış mekan çöp kovası & Adet & 3,000 & 1,569941 \\
\hline 7 & $\begin{array}{l}\text { Y.15.140/10 } \\
\text { Teknik Tarifi } \\
63 \text { mm'ye ka } \\
\text { titreşimli sili } \\
\text { yükleme, yat } \\
\text { Ölçü: Projesi }\end{array}$ & $\begin{array}{l}63 \text { mm'ye kadar kırmataş temin edilerek, makine ile } \\
\text { serme, sulama ve sıkıştırma yapılması } \\
\text { i: } \\
\text { dar kırmataş temin edilmesi, alana dökülmesi, motor grey } \\
\text { ndir ile tabaka tabaka sıkıştırılması için her türlü işçilik, m } \\
\text { ay ve düşey taşıma, boşaltma, müteahhit genel giderleri v } \\
\text { ndeki ölçülere göre hacmi hesaplanır. }\end{array}$ & $\mathrm{m}^{3}$ & $\begin{array}{l}138,200 \\
\text { nesi, sulan } \\
\text { zayiatı, iş }\end{array}$ & $\begin{array}{l}6,526332 \\
\text { lasi, } \\
\text { erinde }\end{array}$ \\
\hline
\end{tabular}


Tablo 3. Yapısal peyzaj işlerine ait teknik şartname ve metraj bilgileri (Devam)

\begin{tabular}{|c|c|c|c|c|c|}
\hline $\begin{array}{l}\text { Sira } \\
\text { No }\end{array}$ & Poz No & İmalatın Cinsi & $\begin{array}{c}\text { Biri } \\
\text { m }\end{array}$ & Miktarı & $\begin{array}{c}\text { Pursantaj } \\
(\%)\end{array}$ \\
\hline 8 & Y.16.050/13 & $\begin{array}{l}\text { Beton santralinde üretilen veya satın alınan ve beton } \\
\text { pompasıyla basılan, C } 16 / 20 \text { basınç dayanım sınıfinda, gri } \\
\text { renkte, normal hazır beton dökülmesi (beton nakli dahil) }\end{array}$ & $\mathrm{m}^{3}$ & 69,100 & 14,435461 \\
\hline
\end{tabular}

Beton üretimine uygun komple beton tesisinde (asgari $60 \mathrm{~m}^{3} / \mathrm{sa}$ kapasiteli, dört gözlü agrega bunkerli kompresörlü ve kumanda kabini ile birlikte bilgisayar kontrollü, en az 50 ton kapasiteli çimento silosu bulunan konveyör bant sistemli, geri kazanım ünitesi, agrega ve beton deneylerini yapabilecek kapasitede laboratuvar, jeneratör, yeteri kadar transmikser ve mobil beton pompası ile en az bir adet yükleyici, katkı tankı ve katkı tartı bunkeri, nem ölçer ve benzeri her türlü ekip ve ekipmana sahip periyodik kalibrasyonu yapılmış beton üretim tesisi) standardına ve projesine uygun, yıkanmış, elenmiş granülometrik kum-çakıl ve/veya kırmataş, çimento, su ve gerektiğinde katkı malzemesi ile C 16/20 sınıfinda üretilen veya bu niteliklere sahip beton tesisinden satın alınan hazır beton harcının; beton kalite kontrollerinin yapılması, transmikserlere yüklenmesi, işyerine kadar nakli, döküm yerine beton pompası ile basılması, yerleştirilmesi, vibratör ile sıkıştırılması, sulanması, soğuktan, sıcaktan ve diğer dış tesirlerden korunması ve bakımının yapılması, gerekli ve yeter sayıda deney için numune alınması ve gerekli deneylerin yapılması için gerekli her türlü işçilik, malzeme ve zayiatı, makine araç, gereç ve laboratuvar giderleri, işyerindeki her türlü yatay ve düşey taşımalar, yükleme ve boşaltmalar, beton bünyesine giren granülometrik kum çakıl veya kırmataşın ve çimentonun temin edildiği, üretildiği veya satın alındığı yerden taşıtlara yüklenmesi, beton tesisine nakli, taşıtlardan boşaltılması, istifi, beton tesisine konulması, beton bünyesinde ve sulama için kullanılan suyun temini ve nakli, beton tesisi ve diğer tüm ekipmanların temini ve amortisman giderleri ile her türlü diğer giderler ve müteahhit genel giderleri ve kârı dâhil, yerinde dökülmüş ve basınç dayanımı C 16/20 olan gri renkte, normal hazir betonun $1 \mathrm{~m}^{3}$ fiyat1:

Ölçü: Projedeki boyutlar üzerinden hesaplanır.

Not:

1) Üretilen veya satın alınan betonun üretildiği tesisin, TSE ve mevzuatının gerektirdiği diğer belgelere sahip olması ve bu belgeleri imalata başlamadan önce idareye vermesi zorunludur. İbraz edilen belgelerin uygun olduğunun tespit ve kullanılmasına müsaade edilmesi kaydıyla ancak, bu tesiste üretilen veya satın alınan ve yürürlükteki mevzuatına göre piyasa arz koşullarını da taşıyan uygunluk belgeli betonun imalatta kullanılması mümkün olacaktır.

2) Betonun satın alınarak temin edilmesi halinde, üzerinde işin adı da belirtilmiş olan faturaların birer suretinin ödeme belgelerine eklenmesi zorunludur.

3) Beton bünyesine ilave olarak konulacak katkı malzemesinin bedeli ayrıca ödenecektir.

4) Pompa kullanılmaması halinde analizden pompa bedeli düşülür.

$9 \begin{array}{lllll}\text { Y.23.010 } & \begin{array}{l}\text { Nervürlü çelik hasırın yerine konulması 1,500-3,000 } \\ \mathrm{kg} / \mathrm{m}^{2}\left(3,000 \mathrm{~kg} / \mathrm{m}^{2} \text { dahil }\right)\end{array}\end{array} \quad$ Ton $\quad \begin{aligned} & \text { 0,464 } \\ & 2,007232\end{aligned}$

Teknik Tarifi:

$5,00 \mathrm{~mm}$ ve daha büyük çaptaki St IVb evsafindaki çubuklardan nokta kaynağı ile hasır şekline getirilmiş çelik hasırın projesine uygun olarak yerine monte edilmesi, şartname ve detaylarına göre bindirme suretiyle eklenmesi ve mesnet teşkili, inşaat yerindeki yükleme, yatay ve düssey taşıma, boşaltma, her türlü malzeme ve zayiatı, işçilik, araç, gereç giderleri, müteahhit genel giderleri ve kârı dâhil, 1 ton hasır çeliğin fiyatı:

Ölçü:

1)Betonarme projesine göre çelik hasırın hesaplanan metre karesi aşağıdaki cetvelde gösterilen ağırlıklarla çarpılarak ton olarak hesaplanır.

2)Projede gösterilmeyen çelik ve ekler hesaba katılmaz.

3)Bağlama teli, $\mathrm{kg} / \mathrm{m}$ ağırlık farkları (cetvele nazaran) mesnet demiri analizdeki zayiat içine dâhil edildiğinden hesaba katılmaz.

Çelik hasır ağırlık tablosu

Çubuk aralarına göre $\mathrm{kg} / \mathrm{m}^{2}$ (tek yön)

Çap kg/m 50 mm, 75 mm, 100 mm, 150 mm, 200 mm, 250 mm, 300 mm 
Tablo 3. Yapısal peyzaj işlerine ait teknik şartname ve metraj bilgileri (Devam)

\begin{tabular}{cccccc}
\hline $\begin{array}{c}\text { Sira } \\
\text { No }\end{array}$ & Poz No & Imalatın Cinsi & Biri & Miktarı & $\begin{array}{c}\text { Pursantaj } \\
(\%)\end{array}$ \\
\hline
\end{tabular}

4.00 .0991 .971 .320 .990 .660 .490 .390 .33

5.00 .1543 .082 .061 .541 .030 .770 .620 .51

5.50 .1873 .732 .491 .871 .240 .930 .750 .62

6.00 .2224 .442 .962 .221 .481 .110 .890 .74

6.50 .2605 .213 .472 .601 .741 .301 .040 .87

7.00 .3026 .044 .033 .022 .011 .511 .211 .01

7.50 .3476 .944 .623 .472 .311 .731 .391 .16

8.00 .3957 .895 .263 .952 .631 .971 .581 .32

8.50 .4458 .915 .944 .452 .972 .231 .781 .48

9.00 .4999 .996 .664 .993 .332 .502 .001 .66

9.50 .55611 .137 .425 .563 .712 .782 .231 .85

10.00 .61712 .338 .226 .174 .113 .082 .472 .06

10.50 .68013 .599 .066 .804 .533 .402 .722 .27

11.00 .74614 .929 .957 .464 .973 .732 .982 .49

11.50 .81516 .3110 .878 .155 .444 .083 .262 .72

12.00 .88817 .7611 .848 .885 .924 .443 .552 .96

$8 \mathrm{~cm}$ yüksekliğinde normal çimentolu buhar kürlü beton

10 Y.26.017/032 parke taşı ile döşeme kaplaması yapılması (her ebat, renk $\quad \mathrm{m}^{2} \quad 113,000 \quad 5,647170$ ve desende)

Teknik Tarifi:

Kaplama yapılacak tabanın düzenlenmesi ve $10 \mathrm{~cm}$ kalınlıkta kum serilmesi, $8 \mathrm{~cm}$ yüksekliğinde doğru kenarlı ve prizmatik normal çimentolu, her ebat, renk ve desende buhar kürlü beton parke taşının kum tabakası üzerine istenen eğimde ve derz aralığında döşenmesi, taşların tokmaklanması, derz aralarının kumla doldurulması, yüzeyinin süpürülmesi, inşaat yerindeki yükleme, yatay ve düşey taşıma, boşaltmalar, her türlü malzeme ve zayiat, işçilik, araç ve gereç giderleri, müteahhit genel giderleri ve kârı dâhil, $1 \mathrm{~m}^{2}$ fiyatı:

Ölçü:

Kaplama yapılan yüzey alanı proje üzerinden hesaplanır.

11 Y.26.017/065 50x20x10 cm boyutlarında normal çimentolu buhar kürlü $\quad$ m $\quad 265,000 \quad 5,512257$

Teknik Tarifi:

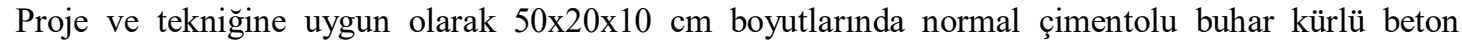
bordürlerin yerine montajı, iki bordür arasındaki birleşim yerlerinin 400 dozlu çimento harcı ile kapatılması her türlü malzeme ve zayiatı, işçilik işyerindeki yükleme, yatay ve düşey taşıma, boşaltma, araç ve gereç giderleri, müteahhit genel giderleri ve kârı dâhil, 1 m fiyatı:

Ölçü:

Bordür boyu projesi üzerinden hesaplanır.

12 Y.26.017/128 $\begin{aligned} & \text { 30x10xserbestboy cm boyutlarında normal çimentolu } \\ & \text { buhar kürlü beton oluk taş dösenmesi (her renk) }\end{aligned} \quad \mathrm{m} \quad 36,000 \quad 0,949070$

Teknik Tarifi:

Proje ve tekniğine uygun olarak 30x10xserbestboy $\mathrm{cm}$ boyutlarında normal çimentolu buhar kürlü beton oluk taşının yerine montajı, iki oluk taşı arasındaki birleşim yerlerinin 400 dozlu çimento harcı ile kapatılması her türlü malzeme ve zayiatı, işçilik işyerindeki yükleme, yatay ve düşey taşıma, boşaltma, araç ve gereç giderleri, müteahhit genel giderleri ve kârı dâhil, 1 m fiyatı:

Ölçü:

Oluk taşı boyu projesi üzerinden hesaplanır. 
Tablo 4. Bitkisel peyzaj işlerine ait teknik şartname ve metraj bilgileri

\begin{tabular}{|c|c|c|c|c|c|}
\hline $\begin{array}{c}\text { Sira } \\
\text { No }\end{array}$ & Poz No & İmalatın Cinsi & Birim & Miktarı & $\begin{array}{c}\text { Pursanta } \\
\mathrm{j}(\%)\end{array}$ \\
\hline \multirow[t]{2}{*}{1} & $04.740 / 11$ & Torf (ince yap1l1, sterilize olmalı, Ph 5-6) & $\mathrm{m}^{3}$ & 25,500 & 1,389353 \\
\hline & $\begin{array}{l}\text { Teknik Tarifi } \\
\text { Çim Tohuml }\end{array}$ & , Gübreler ve Toprak Düzenleyiciler & & & \\
\hline \multirow[t]{2}{*}{2} & 37.013 & $\begin{array}{l}\text { Yumuşak topraklarda } 30 \mathrm{~cm} \text { çapında } 40 \mathrm{~cm} \text { derinliğinde } \\
\text { el ile fidan çukuru açılması }\end{array}$ & 1.000 & 0,108 & 0,187962 \\
\hline & $\begin{array}{l}\text { Teknik Tarifi } \\
\text { Teknik şartn: } \\
\text { çukuru açılm } \\
\text { ve zayiatı, m } \\
\text { genel giderle } \\
\text { (çukur ebatla } \\
\text { Ölçü: } \\
\text { Açllan fidan }\end{array}$ & $\begin{array}{l}\text { ne ve projesinde gösterilen aralıklarla (en fazla } 10 \mathrm{~m} \text { ) yun } \\
\text { 1 ve çıkan toprağın çukur kenarına depo edilmesi için ger } \\
\text { kine, alet ve edevat giderleri ile her nev'i yükleme, taşım } \\
\text { karşllı̆ı dâhil yumuşak topraklarda el ile fidan çukuru a } \\
\text { a göre). } \\
\text { kuru sayılır, bulunan sayı } 1000 \text { 'e bölünür. }\end{array}$ & $\begin{array}{l}\text { di he } \\
\text { boşa } \\
\text { mas }\end{array}$ & $\begin{array}{l}\text { lü iss } \\
\text { müt } \\
\text { er } 10\end{array}$ & $\begin{array}{l}\text { de fidan } \\
\text { nalzeme } \\
\text { kârı ve }\end{array}$ \\
\hline 3 & 37.016 & $\begin{array}{l}\text { Yumuşak topraklarda } 60 \mathrm{~cm} \text { çapında } 80 \mathrm{~cm} \text { derinliğinde } \\
\text { el ile fidan çukuru açılması }\end{array}$ & 1.000 & 0,034 & 0,197244 \\
\hline
\end{tabular}

Teknik Tarifi:

Teknik şartname ve projesinde gösterilen aralıklarla (en fazla $10 \mathrm{~m}$ ) yumuşak toprak zeminlerde fidan çukuru açılması ve çıkan toprağın çukur kenarına depo edilmesi için gerekli her türlü işçilik, malzeme ve zayiatı, makine, alet ve edevat giderleri ile her nev'i yükleme, taşıma, boşaltma; müteahhit kârı ve genel giderler karşılığı dâhil yumuşak topraklarda el ile fidan çukuru açılması beher 1000 adet fiyatı (çukur ebatlarına göre).

Ölçü:

Açılan fidan çukuru sayılır, bulunan sayı bine bölünür.

$\begin{array}{llllll}4 & 37.030 & \text { Çim ve çiçekçilik sahalarının tanzimi } & \text { da } & 0,850 & 1,938129\end{array}$

Teknik Tarifi:

Toprağın bellenmesi, kaba tezeklerin ufalanması, tırmıkla ince tesviyenin yapılması, çim tohumunun elle ekilmesi veya çiçek fidelerinin dikilmesi, ahır gübresinin elenmesi, sahaya serilmesi, bastırılması ve bir defa hortumla sulanması için gerekli her türlü iş̧ilik, malzeme ve zayiatı, makine, alet ve edevat giderleri ile her nev'i yükleme, taşıma, boşaltma; müteahhit kârı ve genel giderler karşllı̆̆ dâhil, çim tohumu veya çiçek fidesi bedeli ve su temini hariç, çim ve çiçeklik sahaların tanzimi beher dekar fiyatı. Ölçü:

Tanzim edilen saha projesi üzerinden, yoksa mahallinde ölçülerek dekar cinsinden hesaplanır.

$\begin{array}{llllll}5 & 37.042 & \begin{array}{l}60 \mathrm{~cm} \text { çapında, } 80 \mathrm{~cm} \text { derinliğindeki çukurlara ibreli } \\ \text { fidanların topraklı dikimi }\end{array} & 1.000 & 0,034 & 0,135402\end{array}$

Teknik Tarifi:

İdarece istenilen ebatta açılmış çukurlara $200 \mathrm{~m}$ mesafe dâhilindeki fidanların tevzii, ambalajlarının açılması, dikimi, çukurların toprakla doldurulması, bastırılması ve ilk suyun $200 \mathrm{~m}$ mesafe dâhilinde taşınarak fidanlara verilmesi, lüzumunda hereklerin çakılması ve fidanların bağlanması için gerekli her türlü işçilik, malzeme ve zayiatı, makine, alet ve edevat giderleri ile her nev'i yükleme, taşıma, boşaltma; müteahhit kârı ve genel giderler karşıllı̆ı dâhil, fidan ve herek bedeli ile su temini hariç, çukurlara ibreli fidanların topraklı dikimi beher 1.000 adet fidan dikim fiyatı çukur ebatlarına göre Ölçü:

Poz No 37.032 deki gibidir.

$\begin{array}{llllll}6 & 37.044 & \begin{array}{l}30 \mathrm{~cm} \text { çapında, } 40 \mathrm{~cm} \text { derinliğindeki çukurlara yapraklı } \\ \text { fidanların veya çalıların topraksız dikilmesi }\end{array} & 1.000 & 0,108 & 0,151969\end{array}$

Teknik Tarifi:

Poz No. 37.(037-042)'deki esaslar ve şartlar dâhilinde çukurlara yapraklı fidanların veya çalıların topraksız dikimi beher 1000 adet fidan dikim fiyatı (çukur ebatlarına göre).

Ölçü:

Poz No 37.032'deki gibidir. 
Tablo 4. Bitkisel peyzaj işlerine ait teknik şartname ve metraj bilgileri (Devam)

\begin{tabular}{|c|c|c|c|c|}
\hline $\begin{array}{c}\text { Sira } \\
\text { No }\end{array}$ & Poz No & İmalatın Cinsi & Miktarı & $\begin{array}{c}\begin{array}{c}\text { Pursanta } \\
\mathrm{j}(\%)\end{array} \\
\end{array}$ \\
\hline \multirow[t]{2}{*}{7} & $37.092 / 3$ & $\begin{array}{l}\text { Bitkisel kaplama yapılacak saha üzerinde } 10-15 \mathrm{~cm} \\
\text { kalınlıkta bitkisel toprağın serilmesi }\end{array}$ & 127,500 & 5,548261 \\
\hline & $\begin{array}{l}\text { Teknik Tarifi: } \\
\text { Ağaçlandırma, } \\
\text { yabancı madd } \\
\text { işçilik, malzem } \\
\text { müteahhit kârı } \\
\text { saha üzerine10 } \\
\text { Ölçü: } \\
\text { Bitkisel toprak } \\
\text { işleminden son }\end{array}$ & $\begin{array}{l}\text { park ve fidanlık sahalarına figüreden alınan toprağın } 10-15 \mathrm{~cm} \\
\text { elerden ayıklanması tohum yetiştirmeye uygun hale getirilmesi } \\
\text { e ve zayiatı, makine, alet ve edevat giderleri ile her nev'i yükle } \\
\text { ve genel giderler karşıllı̆ı̆ dâhil, bitkisel toprağın temini hariç bitk } \\
-15 \mathrm{~cm} \text { kalınlıkta bitkisel toprağın serilmesi beher metreküp fiyatı. } \\
\text { figüre ebadı üzerinden poz no } 37.092 / 2 \text { deki şartlarla metreküp cin } \\
\text { ra kalınlık kontrolü yapılır. }\end{array}$ & $\begin{array}{l}\text { get } \\
\text { taşı } \\
\text { kapl }\end{array}$ & Serme \\
\hline 8 & KGM/2540/K & $\begin{array}{l}\text { Refüjlerde, Bordürle Çevrili Refüjlerde, Eşanjörlerde ve } \\
\text { Düz Sahalarda bitkisel toprak tabakası teşkili (ocak veya } \\
\text { depo) }\end{array}$ & 127,500 & 1,881956 \\
\hline
\end{tabular}

Teknik Tarifi:

KTŞ'nin ilgili kısmındaki esaslar ve şartlar dâhilinde, projesinde belirtilen veya Yapı Denetim Görevlisi tarafindan tespit edilen refüjlerde, bordürle çevrili refüjlerde, eşanjörlerde ve düz sahalarda bitkisel toprak tabakası teşkili.

Birim Fiyata Dâhil Olan Masraflar:

Projenin gerektirdiği kadar bitkisel toprağın; Yapı Denetim Görevlisi’nin göstereceği ocaklardan veya depo yerlerinden kazı veya röpriz suretiyle temini, yüklenmesi, nihai ortalama $100 \mathrm{~m}$ mesafeye kadar taşınması, boşaltılması ve refüjlere, bordürle çevrili refüjlere, eşanjörlere ve düz sahalara kadar taşınması, yabancı maddelerin ayıklanması, projede gösterilen boyut ve şekilde tabakalar halinde serilmesi, suyun iş başından refüjlere, bordürle çevrili refüjlere, eşanjörlere ve düz sahalara taşınması, el tokmakları ile amaca uygun bir şekilde sıkıştırılması ile aşağıda "Birim Fiyata Dâhil Olmayan Masraflar" başlığı altında sayılanlar dışında kalan diğer bütün işlerin yapılması için gerekli olan her türlü işçilik, malzeme, makine, alet ve araç giderleri ile yüklenici kârı ve genel masraflar.

Birim Fiyata Dâhil Olmayan Masraflar:

Suyun teinin yerinden iş başına, bitkisel toprağın nihai ortalama 100 m'den fazla mesafeye taşınması, sulama yapılmasi.

Ölçü:

Sulanmış ve sıkışmış bitkisel toprak tabakasının kalınlığı ile bu tabaka alanının çarpılması suretiyle bulunan $\mathrm{m}^{3}$ cinsinden hacmidir.

Ödeme: Birim Fiyat Teklif Cetvelinde Poz KGM/2540/K'daki "Refüjlerde, Bordürle Çevrili Refüjlerde, Eşanjörlerde ve Düz Sahalarda Bitkisel Toprak Tabakası Teşkili" (Ocak veya Depo Malzemesinden)" $\mathrm{m}^{3}$ birim fiyatı üzerinden yapılır.

Not:

Bitkisel toprak taşımasına ait hacim, yukarıda ölçü maddesinde belirtilen hacimdir.

\begin{tabular}{cllccc}
\hline 9 & P-Özel 10 & $\begin{array}{l}\text { Yanmış elenmiş çiftlik gübresi (Kokusuz, her türlü } \\
\text { yabancı maddelerden arı olmalıdır) }\end{array}$ & \multirow{2}{*}{$\mathrm{m}^{3}$} & \multirow{2}{*}{34,000} & 2,541809 \\
\hline 10 & P-Özel 5 & Peyzaj projesinde yer alan bitkilerin temini & $\mathrm{Adet}$ & 1,000 & 9,285079 \\
\hline 11 & P-Özel 6 & Lolium perenne L. "Allstarter" (İngiliz Çimi) & $\mathrm{Kg}$ & 15,300 & 0,423303 \\
\hline 12 & P-Özel 7 & Poa pratensis L. "Bluechip" (Çayır salkım otu) & $\mathrm{Kg}$ & 10,200 & 0,533780 \\
\hline 13 & P-Özel 8 & Festuca rubra rubra L. "Rosinante" (Kırmııı yumak) & $\mathrm{Kg}$ & 17,850 & 0,467164 \\
\hline 14 & P-Özel 9 & Festuca arundinacea Schreb "Tomcat” (Kamışsı yumak) & $\mathrm{Kg}$ & 7,650 & 0,211651
\end{tabular}

Daha sonra proje alanındaki canlı ve cansız malzemeye yönelik malzeme temini ve işçilik için elde edilen metrajların her birisi ayrı ayrı kendi birim fiyatları ile çarpılarak yaklaşık maliyet hesaplaması yapılmışıır. Sonuç olarak yapısal uygulama için 62.790,80 TL'ye, bitkisel uygulama için 20.811,07 TL'ye ihtiyaç duyulmaktadır. Projenin uygulanması için toplam 83.601,87 TL gerekmektedir. Tablo 5'de yapısal peyzaj uygulamasına yönelik yaklaşık maliyet cetveli ve Tablo 6'da bitkisel peyzaj uygulamasına yönelik yaklaşı maliyet cetveli yer almaktadir. 
Tablo 5. Yapısal peyzaj uygulamasına yönelik yaklaşık maliyet cetveli

\begin{tabular}{|c|c|c|c|c|c|c|}
\hline Sira & Poz No & İmalatın Cinsi & Birim & Miktarı & $\begin{array}{l}\text { Birim } \\
\text { Fiyatı }\end{array}$ & Tutarı \\
\hline 1 & $04.032 / 20 \mathrm{~B}$ & $\begin{array}{l}3 \text { cm kalınlıkta Blok antistatik kauçuk zemin kaplaması, } \\
\text { Çarpma etkisini azaltan yüzey kaplamaları (TS EN } \\
\text { 1176-1, TS EN 1177-1) }\end{array}$ & $\mathrm{m}^{2}$ & 47,000 & 55,00 & $2.585,00$ \\
\hline 2 & $27.581 / 1 \mathrm{~A}$ & Tesviye tabakası & $\mathrm{m}^{2}$ & 691,000 & 20,63 & $14.255,33$ \\
\hline 3 & P-Özel 1 & Tek Kuleli Oyun Parkı & Adet & 1,000 & $7.812,50$ & $7.812,50$ \\
\hline 4 & P-Özel 2 & Figürlü tahterevalli (4’lü) & Adet & 1,000 & $3.750,00$ & $3.750,00$ \\
\hline 5 & P-Özel 3 & Alüminyum döküm ayaklı ahşap bank & Adet & 6,000 & 625,00 & $3.750,00$ \\
\hline 6 & P-Özel 4 & Kare metal dış mekan çöp kovası & Adet & 3,000 & 437,50 & $1.312,50$ \\
\hline 7 & Y.15.140/10 & $\begin{array}{l}63 \text { mm'ye kadar kırmataş temin edilerek, makine ile } \\
\text { serme, sulama ve sıkıştırma yapılması }\end{array}$ & $\mathrm{m}^{3}$ & 138,200 & 39,48 & $5.456,14$ \\
\hline 8 & Y.16.050/13 & $\begin{array}{l}\text { Beton santralinde üretilen veya satın alınan ve beton } \\
\text { pompasıyla basılan, C } 16 / 20 \text { basınç dayanım sınıfında, } \\
\text { gri renkte, normal hazır beton dökülmesi (beton nakli } \\
\text { dahil) }\end{array}$ & $\mathrm{m}^{3}$ & 69,100 & 174,65 & $12.068,32$ \\
\hline 9 & Y.23.010 & $\begin{array}{l}\text { Nervürlü çelik hasırın yerine konulması } 1,500-3,000 \\
\mathrm{~kg} / \mathrm{m}^{2}\left(3,000 \mathrm{~kg} / \mathrm{m}^{2} \text { dahil }\right)\end{array}$ & $\mathrm{t}$ & 0,464 & $3.616,56$ & $1.678,08$ \\
\hline 10 & Y.26.017/032 & $\begin{array}{l}8 \mathrm{~cm} \text { yüksekliğinde normal çimentolu buhar kürlü beton } \\
\text { parke taşı ile döşeme kaplaması yapılması (her ebat, } \\
\text { renk ve desende) }\end{array}$ & $\mathrm{m}^{2}$ & 113,000 & 41,78 & $4.721,14$ \\
\hline 11 & Y.26.017/065 & $\begin{array}{l}50 \times 20 \times 10 \mathrm{~cm} \text { boyutlarında normal çimentolu buhar } \\
\text { kürlü beton bordür döșenmesi (pahl, her renk) }\end{array}$ & $\mathrm{m}$ & 265,000 & 17,39 & $4.608,35$ \\
\hline 12 & Y.26.017/128 & $\begin{array}{l}\text { 30x10xserbestboy } \mathrm{cm} \text { boyutlarında normal çimentolu } \\
\text { buhar kürlü beton oluk taş dösenmesi (her renk) }\end{array}$ & $\mathrm{m}$ & 36,000 & 22,04 & 793,44 \\
\hline & & & & & \multicolumn{2}{|c|}{ Toplam: $62.790,80$} \\
\hline
\end{tabular}

Tablo 6. Bitkisel peyzaj uygulamasına yönelik yaklaşık maliyet cetveli

\begin{tabular}{|c|c|c|c|c|c|c|}
\hline Sira & Poz No & İmalatın Cinsi & Birim & Miktarı & Birim Fiyat1 & Tutar1 \\
\hline 1 & $04.740 / 11$ & Torf (ince yapıl1, sterilize olmalı, $\mathrm{Ph} 5-6$ ) & $\mathrm{m}^{3}$ & 25,500 & 45,55 & $1.161,53$ \\
\hline 2 & 37.013 & $\begin{array}{l}\text { Yumuşak topraklarda } 30 \mathrm{~cm} \text { çapında } 40 \mathrm{~cm} \text { derinliğinde el } \\
\text { ile fidan çukuru açılması (108 adet) }\end{array}$ & 1.000 & 0,108 & $1.455,00$ & 157,14 \\
\hline 3 & 37.016 & $\begin{array}{l}\text { Yumuşak topraklarda } 60 \mathrm{~cm} \text { çapında } 80 \mathrm{~cm} \text { derinliğinde el } \\
\text { ile fidan çukuru açılması ( } 34 \text { adet) }\end{array}$ & 1.000 & 0,034 & $4.850,00$ & 164,90 \\
\hline 4 & 37.030 & Çim ve çiçekçilik sahalarının tanzimi $\left(850 \mathrm{~m}^{2}\right)$ & da & 0,850 & $1.906,25$ & $1.620,31$ \\
\hline 5 & 37.042 & $\begin{array}{l}60 \mathrm{~cm} \text { çapında, } 80 \mathrm{~cm} \text { derinliğindeki çukurlara ibreli } \\
\text { fidanların topraklı dikimi ( } 34 \text { adet) }\end{array}$ & 1.000 & 0,034 & $3.329,38$ & 113,20 \\
\hline 6 & 37.044 & $\begin{array}{l}30 \mathrm{~cm} \text { çapında, } 40 \mathrm{~cm} \text { derinliğindeki çukurlara yapraklı } \\
\text { fidanların veya çalıların topraksız dikilmesi (108 adet) }\end{array}$ & 1.000 & 0,108 & $1.176,38$ & 127,05 \\
\hline 7 & $37.092 / 3$ & $\begin{array}{l}\text { Bitkisel kaplama yapılacak saha üzerinde } 10-15 \mathrm{~cm} \\
\text { kalınlıkta bitkisel toprak serilmesi }\end{array}$ & $\mathrm{m}^{3}$ & 127,500 & 36,38 & $4.638,45$ \\
\hline 8 & $\begin{array}{l}\mathrm{KGM} / 2540 / \\
\mathrm{K}\end{array}$ & $\begin{array}{l}\text { Refüjlerde, Bordürle Çevrili Refüjlerde, Eşanjörlerde ve } \\
\text { Düz Sahalarda bitkisel toprak tabakası teşkili (ocak veya } \\
\text { depo) }\end{array}$ & $\mathrm{m}^{3}$ & 127,500 & 12,34 & $1.573,35$ \\
\hline 9 & P-Özel 10 & $\begin{array}{l}\text { Yanmış elenmiş çiftlik gübresi (Kokusuz, her türlü yabancı } \\
\text { maddelerden ari olmalıdır) }(4 \mathrm{~cm})\end{array}$ & $\mathrm{m} 3$ & 34,000 & 62,50 & $2.125,00$ \\
\hline 10 & P-Özel 5 & $\begin{array}{l}\text { Peyzaj projesinde yer alan bitkilerin temini (toplam } 142 \\
\text { bitki için) }\end{array}$ & Adet & 1,000 & $7.762,50$ & $7.762,50$ \\
\hline 11 & P-Özel 6 & Lolium perenne L. “Allstarter” (İngiliz Çimi) & $\mathrm{Kg}$ & 15,300 & 23,13 & 353,89 \\
\hline 12 & P-Özel 7 & Poa pratensis L. "Bluechip" (Çayır salkım otu) & $\mathrm{Kg}$ & 10,200 & 43,75 & 446,25 \\
\hline 13 & P-Özel 8 & Festuca rubra rubra L. "Rosinante" (Kır. yumak) & $\mathrm{Kg}$ & 17,850 & 21,88 & 390,56 \\
\hline 14 & P-Özel 9 & Festuca arundinacea Schreb “Tomcat” (Kamışsı yumak) & $\mathrm{Kg}$ & 7,650 & 23,13 & 176,94 \\
\hline
\end{tabular}




\section{Sonuç ve Öneriler}

Proje tasarım sürecinin önemi kadar projenin alana tasarlanan özelliklere uygun olarak aplike edilmesi de önem taşımaktadır. Özellikle ekonomik koşulların yetersizliği istenilen malzeme, teknik ya da işçiliğin uygulanamamasına neden olmaktadır. Bu nedenle yaklaşık maliyetin önceden bilinmesi gerekli bütçenin temin edilmesini kolaylaştırmaktadır. Bu aşamada metraj, keşif ve birim fiyat analizlerinin yapılması gerekmektedir. Bunun için de yapısal ve bitkisel peyzaj uygulama projeleri ile detay projelerinin eksiksiz ve doğru olarak çizilmesi önem taşımaktadır. Çünkü bu projelerden elde edilen verilere göre hesaplama yapılmaktadır. Ayrıca teknik şartnamelerde çizimlerden elde edilemeyecek veri teminleri için gerekli unsurları sağlamaktadır. "Peyzaj Tasarımı/Planlama Projeleri İle Kontrollük ve Danışmanlık Hizmetleri Asgari Ücret Tarifesi ve Şartnamesinde” proje tasarım aşamaları ve ihale dosyası hazırlama hizmetlerinde teknik şartnamelerin hazırlanması, metraj, keşif ve maliyet analizlerinin yapılması ile ihale belgelerinin hazırlanmasına yönelik bilgi ve standartlar verilmektedir. Böylece projeyi tasarlayan peyzaj mimarının metraj, keşif ve diğer ayrıntıları da hazırlaması güvence altına alınmış olmaktadır. Dolayısıyla tasarımı yapılan projenin doğru malzeme, teknik ve işçilik kullanılarak alana uygulanması mümkün olabilecektir.

Sonuç olarak, uygulaması yapılmayan bir projenin bulunduğu alana ya da kente katkı sağlaması mümkün değildir. Bu nedenle yaklaşık maliyet hesaplarıyla uygulama için gerekli bütçenin önceden öğrenilmesi ve tasarımla birlikte uygulamaya da bir bütçe ayrılması önem taşımaktadır.

\section{Teşekkür}

Yapısal ve bitkisel peyzaj tasarımı yapılmış olan projenin yaklaşık maliyet hesaplarının oluşturulması sürecinde yardım ve desteğini esirgemeyen Peyzaj Yüksek Mimarı Elif Gürbüz’e teşekkürlerimi sunarım.

\section{Kaynaklar}

1. PMO (2006). Yönetmelikler (Serbest peyzaj Mimarlık Müşavirlik (SMM) Hizmetleri Uygulama, Mesleki Denetim, Bürolarının Tescili ve Asgari Ücret Yönetmeliği/ Peyzaj Tasarım Planlama Projeleri ve Kontrollük Danışmanlık Hizmetleri Asgari Ücret Tarifesi ve Şartnamesi) 2006. TMMOB Peyzaj Mimarları Odası, 7. Dönem Yönetim Kurulu, Ankara.

2. PMO (2017). Yapı Ruhsat Aşamasında Peyzaj Projesi. TMMOB Peyzaj Mimarları Odası, Ankara.

3. Barış ME (2004). Peyzaj tasarımı süreci. Peyzaj Mimarlığı Dergisi, TMMOB Peyzaj Mimarları Odası Yayını, 1-2: 115-121.

4. Gürer L (1990). Temel Tasarım. İstanbul Teknik Üniversitesi Matbaası, sayı:1496, ss.136, Gümüşsuyu.

5. Hasol D. (2005). Ansiklopedik Mimarlık Sözlüğü, 9. Baskı, Yapı Yayın, ISBN:975-7438-30-8, ss.511, İstanbul.

6. Hiss JE, Booth NK (2002). Residential Landscape Architecture Design Process for the Private Residence. 3rd ed. Upper Saddle River, ISBN:0-13-027827-0, ss.420, NJ, USA.

7. Korkut AB, Şişman EE, Özyavuz M (2010). Peyzaj Mimarlığı. Birinci Baskı, ISBN: 978-605-88381-09, Verda Yayıncilik.

8. Reid GW (1993). From Concept to Form in Landscape Design. Van Nostrand Reinhold, ISBN: 0-44201247-0, ss.162, New York.

9. Seçkin ÖB (2003). Peyzaj Uygulama Tekniği. İstanbul Üniversitesi, Orman Fakültesi Yayını, ISBN:975404-507-0, ss.528, İstanbul.

10. Seçkin NP, Seçkin YÇ, Seçkin ÖB (2011). Sürdürülebilir Peyzaj Tasarımı ve Uygulama İlkeleri. Birinci basım. Literatür yayınları, ISBN: 978-975-04-0582-2, ss.223, İstanbul.

11. Taşpınar AS (1977). Mimaride Gün Işı̆̆ı \& Gaziantep Kampusuna Uygulanması. Orta Doğu Teknik Üniversitesi Mimarlık Fakültesi Basımı, ss.161, Ankara.

12. Tokol AS (2000). Landscape Design Lectures. METU Faculty of Architecture Press, ISBN:975-429-1624, ss.152, Ankara.

13. URL1 (2018). http://www.ankarakulturturizm.gov.tr/TR,152391/iklim.html. (Erişim:02.09.2018).

14. URL2 (2018). https://www.birimfiyat.net/. (Erişim:29.11.2018).

15. URL3 (2018). https://www.kikkararlari.com/parasal-tutar-guncelleme/index.html. (Erişim:29.11.2018). 